Semchuk N., Varava I.

UDC 1:34 (043.2) + 343.9(045)

\author{
N. Semchuk, \\ $\mathrm{PhD}$, Senior Lecturer \\ I. Varava, \\ Senior Lecturer
}

\title{
OSVALD SPENGLER'S VIEWS ON LEGISLATION: THE CRIMINAL LEGAL ASPECTS
}

\author{
National Aviation University \\ Kosmonavta Komarova Avenue, 1, 03680, Kyiv, Ukraine \\ E-mails: natalybarrister@ukr.net, varavairina8@gmail.com
}

The purpose of this work is to analyze O. Spengler's views on the essence of law and legal dynamics in the impact of criminal law and criminology. Research methods: historical, logical, comparative and other. Results: the paper is analyzing A. Spengler's views on the substance of law and jurisprudence as expressed in Volume 2 of The Twilight of the West. The work is one of the first attempts to explore O. Spengler's scientific heritage (using the work of foreign researchers) on the understanding of the essence of law and legal dynamics in context of criminal law. The practical value of this work is that it, based on the analysis of foreign sources, formulated conclusions that can be used in context of contemporary jurisprudence and criminalization policies. As in ancient times, when drafting laws, politicians do not pay much attention to the extent to which they reflect the current conditions of life of society, and, accordingly, fulfill their purpose of protecting public life from crime.

Keywords: O. Spengler; dynamic legal theory; legislation; criminalization theory; criminology.

Introduction. Oswald Spengler (1880-1936) is considered a prominen tfigure in the Weimar Republic. Hisbook, the Untergang des Abendlandes (firs tpart, published in 1918, the second in 1922) was the most widely discussed book, and had a great influence on the thinkers of the interwar period.Among the interesting features of the originalstyle of this book is that evenits title can be translated in different ways, and although the variants are close in meaning, they reflect different semanticnuances. Theword "der Untergang" can mean both the collapse, the death, and just thet wilight twilight, and thes unset of the celestialluminary, followed by the inaugural dawn. And a not word inthephrase - das Abendlandes (literally - eveningland) - one of the specific German terms to refer to Western Europe. Unfortunately, thet ranslation does not convey this play of words - "twilight" and "eveningland." Currently the rearesuch optionsas "Twilight of Europe", "West of Europe", "The collapse of
Europe". As we can see, in principle, they all have the right to exist - such philosophical ambiguity was in corporated into the title of the book by the author himself.

The work of the primary sources was greatly influenced by the work of Doctors of Philology M. Lanowyk and Z. Lanowyk, The Twilight of the West, by O. Spengler: A Providence Model of Science, where, among other things, they point to the fact that O. Spengler has "non-scientific" language in his work, for which he has been repeatedly criticized by contemporaries or scholars for decades to come, not least from the materialist / positivist camp. In somep laces, such a statement and course of thought was explained by the manifestation of creative imagination in science [1, p. 9].

Along with Eugen Ehrlich, founder of the sociology of law, Spengler also draws a link between crime (as a matter of criminal law) and acute statistics to determinet reconditions of criminalization. Given the above, the study of the 
views of foreign and domestic scientists on Spengler's creative heritage, has great importance for criminal law. Ananalys is of the views on the nature of law (including criminal law), justice (which is a factor in counteracting crimes in society) and legal dynamics can help to understand the nature of the crime and the factors of criminalization.

Analysis of research and publications. $O$. Spengler's creative heritage attracts the constant attention of domestic and foreign scientists from different fields. Over 50 scientists have analyzed O. Spengler's legacy in the Scopus database in the last 10 years. Among the scientists conducting research in this fields hould be singled out M. Lanovik, A. Sirotova and M. Lutz.

The purpose - conduct an analysis of the views on the nature of law (including criminal law), justice (which is a factor in counteracting crime in society) and legal dynamics (which will help to understand the nature of crime and the factors of criminalization).

Presentation of the basic material. The work of primary sources was greatly influenced by the work of Doctors of Philology M. Lanowyk and Z. Lanowyk, "The Twilight of the West by A. Spengler: The Providence Model of Science," where, among other things, they point out that the fact that O. Spengler is undeniable today uses "nonscientific" (not entirely scientific) language in his work, for which he has been repeatedly criticized by contemporaries or scholars for decades to come, not least from the materialist/positivist camp. In some places, such a statement and course of thought was explained by the manifestation of creative imagination in science [1, p. 9]. It is to be agreed with Lanowik's view that this is a metaphorically, allegorical letter with pronounced features of a profane work; Moreover, anyone who really delves into his reading can recognize the "mystical aura" of the impact of this text. In his context, emasculated, emotionless scholarly work, written according to the requirements of established patterns, can also be perceived as "fiercely ossified" as part of a twilight of spirituality that, according to the researcher, "inspires anxiety" [1, p. 9].

It is perhaps this style of writing that is en- thralling, metaphorical, yet deeply thoughtful and thorough, scientific in nature, and the reason why a book such as The Twilight of the West became a European best-seller in its day (which is not at all) characteristic of scientific works).

In many respects, the rethinking of O. Spengler's creative legacy from the perspective of lawyers began with the work of Dr. Lutz, Oswald Spengler and Jurisprudence (2014). The author, who is also a lawyer and partner of a well-known law firm in Germany, received a $\mathrm{PhD}$ in law based on his publication on this monograph. Unfortunately, this fundamental work is now 328 pages long. has not been translated into Ukrainian or Russian. The monograph is based on the use of O. Spengler's works in legal science between 1918 and 1945, and was conducted, in particular, within the framework of "Dynamic Legal Theory" (Oswald Spengler und die Jurisprudenz. Die Spenglerrezeption in der Rechtswissenschaft zwischen 1918 und 1945b ins der ondere inner "Dynamischen Rechtslehre", der Rechtshistoriographie und der Staatsrechtswissenschaft) [2, p. 3], legal historiography and constitutional and criminal law.

In his study, Lutz focuses on Spengler's influence on lawyers, thus closing the gap in the study of Spengler's creative heritage. First of all, lawyers in different contexts have confirmed Spengler's position on legal dynamics. At the same time, the work does part of the legal intellectual history, as Spengler has always approached, in civil law, the confessor of social and life law and the irrational philosophy of life philosophy. In the field of constitutional law, Spengler was known for a rather radical and intellectual analysis of modernity [2, p. 3]. Perhaps the most diverse education of $\mathrm{O}$. Spengler himself and his wide range of scientific interests has attracted and continues to attract not only philosophers, but also other researchers in many fields of knowledge, from mathematics to translation, to his scientific heritage. First of all, it should be pointed out that in order to understand O. Spengler's views on the right, one should start with the basics of the author's cultural and philosophical views, based on such concepts as culture and civilization.

Here it is worth agreeing with A. Sirotova that the German theorist creates his own method of studying history, within which he examines a number of cultural formations of antiquity, and on the basis of 
parallels with modernity tries to determine the fate of the West [3, p. 83]. Cosmina V.G., who studies the problems of the methodology of civilizational analysis of the historical process, rightly points out that O. Spengler studied the theory of local civilizations, doing so very reasonably and fundamentally. Readers were amazed by the grandiose picture of world history itself and the author's unusual approach to its coverage. Soviet social studies showed attention to the work of the German thinker, mostly in the context of the widespread campaign of "critique of bourgeois philosophy of history", which began in the second half of the 1960s. Official science was characterized as "the German idealist philosopher, one of the theoretical precursors of German fascism", and "Twilight of the West" - a work that "had great success among the ideologists of imperialism" [4, p. 190].

Spengler created a grand comparative picture of the formation and decline of worldviews, sciences, languages, arts, peoples, philosophical systems, social structures, politics, religions, etc. in their organic unity in each period of a particular culture - especially Western, ancient and Arab - as foreign manifestation of its symbol and temporal state of mind. The 198 analysis of the Spengler historical method shows that he incorporated many methodological achievements of the most influential at that time, especially in Germany, schools of philosophy of history and historiography, creatively conceived, supplemented and generalized by the philosopher [4, p. 200]. At the same time, without prejudice to the analysis of the entire creative heritage of O. Spengler, from the entire Spengler panorama of the development of cultures within the framework of 8 civilizations, in this article we will highlight only the aspect directly related to the development of European (including criminal) law.

Conclusions. Given the above, we can conclude that the views of O. Spengler, who proposed to investigate criminal law both in historical genesis and in conjunction with the life of a society at some time in many respects far ahead of its time. Even contemporary jurisprudence and criminalization policies are in the early stages of understanding these ideas. As in ancient times, when drafting laws, politicians do not pay much atten- tion to the extent to which they reflect the current conditions of life of society, and, accordingly, fulfill their purpose of protecting public life from crime.

In legal education, to which O. Spengler also paid attention, the philological approach, as the heir to medieval scholasticism, remains largely dominant, although in criminal law it has been partly replaced by a socio-economic approach, taking into account meaningful historical experience.

\section{References}

1. Лановик М.Б., Лановик 3.Б. «Смеркання Заходу» Освальда Шпенглера: провіденційна модель науки. Питання літературознавства. 2018. № 98. C. 7-22. https://doi.org/10.31861/ pytlit2018.98.007

2. Lutz M.K. Oswald Spengler und die Jurisprudenz. Tübingen: Mohr Siebeck, 2014. 328 c.

3. Сиротова А.А. Аналіз цивілізаційної концепції розвитку людства О. Шпенглера. Науковий вісник Уэсгородського національного універсиmemy. 2005. № 2. C. 82-90.

4. Космина В.Г. Історичний метод Освальда Шпенглера. Украӥнський історичний журнал. 2006. № 6. C. 189-203.

5. Spengler O. Der Untergang des Abendlandes: Umrisseeinerorphologie der weltgeschichte. Zwaiter Band. Welthistorishen Prespektiven. München: Beck, 1922. URL: http:// gutenberg.spiegel.de/.

6. Ehrlich E. Fundamental Principles of the Sociology of Law. Cambridge: Harvard University Press, 1936. $450 \mathrm{p}$.

\section{References}

1. Lanovyk M.B., Lanovyk Z.B. «Smerkannia Zakhodu» Osvalda Shpenglera: providentsiina model nauky. Pytannia literaturoznavstva. 2018. № 98. P. 7-22.

2. Lutz M.K. Oswald Spengler und die Jurisprudenz. Tübingen: Mohr Siebeck, 2014. 328 p.

3. Syrotova A.A. Analiz tsyvilizatsiinoi kontseptsii rozvytku liudstva O. Shpenhlera. Naukovyi visnyk Uzhhorodskoho natsionalnoho universytetu. 2005. № 2. P. 82-90.

4. Kosmyna V.H. Istorychnyi metod Osvalda Shpenglera. Ukrainskyi istorychnyi zhurnal. 2006. № 6. P. 189-203.

5. Spengler O. Der Untergang des Abendlandes : 
Umrisseeinerorphologie der weltgeschichte. 6. Ehrlich E. Fundamental Principles of the SociZwaiter Band. Welthistorishen Prespektiven. ology of Law. Cambridge: Harvard University Press, München: Beck, 1922. URL: http:// guten- 1936. $450 \mathrm{c.}$

berg.spiegel.de/.

Н. Семчук, I. Варава

\title{
ПОГЛЯДИ О. ШПЕНГЛЕРА НА СУТНІСТЬ ЮРИСПРУДЕНЦІЇ: КРИМІНАЛЬНО-ПРАВОВИЙ АСПЕКТ
}

\author{
Національний авіаційний університет \\ проспект Космонавта Комарова, 1, 03680, Київ, Україна \\ E-mails: natalybarrister@ukr.net, varavairina8@gmail.com
}

\begin{abstract}
Метою даної роботи є аналіз поглядів О. Шпенглера на сутність права і правову динаміку. Методи дослідження: історичний, логічний, порівняльно-правовий та ін. Результати: у роботі розглядаються погляди О. Шпенглера на сутність права та юриспрудениії, висловлені ним у 2 томі «Смеркання Заходу». Робота є однією з перших спроб дослідити наукову спадщину О. Шпенглера (з використанням робіт зарубіжних дослідників) з питань розуміння ним сутності права і правової динаміки в контексті кримінального права. Обговорення: Освальд Шиенглер (1880-1936) вважсається видатною особистістю періоду Веймарської республіки. Його книга «Смеркання Заходу» була найчастіше обговорюваною книгою тієї епохи, і мала величезний вплив на мислителів міжвоєнного періоду. О. Шпенглер різко критикує середньовічну схоластику та сліпе запозичення давніх зразків права. Саме як наслідок иієї боротьби О. Шиенглер вказує на кризові явища, які особливо помітні й у сучасній юриспрудениії. «Західний юрист стає філологом, а практичний досвід життя замінюється науковим досвідом суто логічного розкладу і поєднання правових понять, щчо базується виключно на собі. Сьогоднішня юриспруденція в значній мірі є спадщиною схоластики середньовіччя». Саме для того, щоб, як влучно зазначає сам О. Шпенглер, вивчена юристом наука не залишалася «чужою для світу», $i$ потрібні подальші розробки в сфері динамічної теорії права. Особливо помітна така розрізненість у галузі кримінального права. Враховуючи викладене, можна зробити висновок, щьо погляди О. Шпенглера, який пропонував досліджувати право як в історичному генезисі, так $і$ в поєднанні з життям певного суспільства у певний час багато в чому випередили свій час. Навіть сучасна наука кримінального права знаходиться на початковій стадії осмислення цих ідей. Як і в більш давні часи, розробляючи закони, політики не дуже зважають на те, наскільки вони будуть відображати сучасні умови життя суспільства, $i$, відповідно, виконувати своє призначення. В юридичній освіті, якій також приділяв увагу О. Шпенглер, філологічний підхід як спадкоємеиь середньовічної схоластики багато в чому продовжує домінувати, він був частково замінений сочіально-економічним підходом з урахуванням осмисленого історичного досвіду.
\end{abstract}

Ключові слова: О. Шпенглер; динамічна правова теорія; законодавство; теорія криміналізації; кримінологія. 